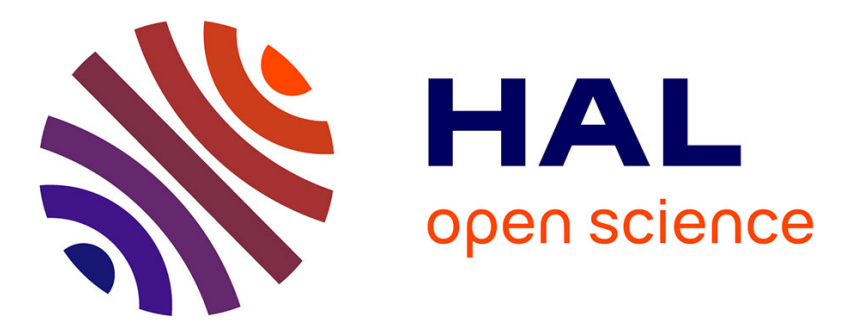

\title{
Coronary artery disease is more severe in patients with primary hyperparathyroidism
}

\author{
Omar Koubaity, Damien Mandry, Phi-Linh Nguyen-Thi, Florence Bihain, \\ Claire Nomine-Criqui, Léa Demarquet, Valérie Croise-Laurent, Laurent \\ Brunaud
}

\section{To cite this version:}

Omar Koubaity, Damien Mandry, Phi-Linh Nguyen-Thi, Florence Bihain, Claire Nomine-Criqui, et al. Coronary artery disease is more severe in patients with primary hyperparathyroidism. Surgery, 2020, 167 (1), pp.149-154. 10.1016/j.surg.2019.05.094 • hal-03254728

\section{HAL Id: hal-03254728 \\ https://hal.univ-lorraine.fr/hal-03254728}

Submitted on 21 Dec 2021

HAL is a multi-disciplinary open access archive for the deposit and dissemination of scientific research documents, whether they are published or not. The documents may come from teaching and research institutions in France or abroad, or from public or private research centers.
L'archive ouverte pluridisciplinaire HAL, est destinée au dépôt et à la diffusion de documents scientifiques de niveau recherche, publiés ou non, émanant des établissements d'enseignement et de recherche français ou étrangers, des laboratoires publics ou privés.

\section{(ㅇ)(1) $\$$}

Distributed under a Creative Commons Attribution - NonCommercial| 4.0 International 
Coronary artery disease is more severe in patients with primary hyperparathyroidism.

\section{Authors: Omar KOUBAITY ${ }^{1}$, Damien MANDRY ${ }^{1}$, Phi-Linh NGUYEN-THI \\ 2, Florence BIHAIN ${ }^{3}$, Claire NOMINE-CRIQUI ${ }^{3}$, Léa DEMARQUET ${ }^{4}$, Valérie CROISE-LAURENT ${ }^{1}$, Laurent BRUNAUD ${ }^{3,5}$}

1: University of Lorraine, CHU Nancy, Brabois Hospital, Department of Radiology, Nancy, France

2: University of Lorraine, CHU Nancy, Medical Evaluation Departement, Department of Clinical Research Support PARC, Nancy, France

3 : University of Lorraine, CHU Nancy, Brabois Hospital, Department of

Surgery, Section of Endocrine, Thyroid and Metabolic Surgery, Nancy, France

4: University of Lorraine, CHU Nancy, Department of Endocrinology,

Diabetology and Nutrition, Nancy, France

5: University of Lorraine, INSERM U1256, « Nutrition, Genetics,

Environmental Risks », Faculty of Medicine, Nancy, France

$40^{\text {th }}$ Annual Meeting of the American Association of Endocrine

Surgeons in Los Angeles, California from April 7-9, 2019

Corresponding author: Laurent BRUNAUD, Department of Surgery, CHU

Nancy (Brabois $3^{\text {ème }}$ étage), Université de Lorraine, 11 allée du morvan,

54511 Vandoeuvre-les-Nancy, FRANCE, Tel: (33)-383153120; Fax: (33)-

383153121 Email: I.brunaud@chu-nancy.fr and I.brunaud@gmail.com 
Background: Primary hyperparathyroidism (PHPT) is associated with an increased cardiovascular mortality, but mechanisms underlying this association are unclear. The goal of this study was to evaluate coronary artery calcifications via the coronary calcification score (CAC score) in PHPT patients, to compare with control subjects, and to identify risk factors for high to intermediate risk CAC scores (CAC score > 100).

Method: Cross-sectional study of PHPT patients without a history of coronary artery disease, diabetes, or severe chronic kidney disease. CAC scores were compared with a cohort of population-based control subjects.

Results: The mean CAC score was $120 \pm 344$ in 130 PHPT patients. The CAC score was > 100 in 27 patients $(21 \%)$. When compared with control subjects, the percentage of positive CAC scores was similar in PHPT patients (53 versus $50 \%$ ); however, positive CAC scores were at the $67^{\text {th }}$ percentile of the control subjects cohort $(p<0.001)$. In multivariable regression, patient age (1.1; 1.1-1.2; $p<0.001)$, patients in the mild normocalcemic PHPT group (5.1; $1.1-22.6 ; p=0.037)$, and the need for antihypertensive medications $(6.1 ; 1.8$ - 20.9; $p<0.001)$ remained independent predictors for a CAC score $>100$.

Conclusion: Positive CAC scores were greater in PHPT patients than in population-based control subjects. These study data may provide new criteria for parathyroidectomy in patients with PHPT. 


\section{INTRODUCTION}

Primary hyperparathyroidism (PHPT) has been associated with an increased cardiovascular mortality, but the mechanisms underlying this association have not been elucidated (1-4). Moreover, in asymptomatic and/or mild PHPT, there is a lack of consensus about cardiac risk with some but not all studies reporting an increase in incidence of cardiovascular events (1-5). Coronary artery calcification (CAC) is a marker of atherosclerosis, which is proportional to the extent and severity of coronary artery disease and can be easily evaluated with unenhanced cardiac computed tomography $(2,6)$. The coronary calcium score (CAC score) is a strong and independent risk predictor for a 10-year coronary event in the general population: there is a $22-28 \%$ when the $\mathrm{CAC}$ is $>400$ (high risk), $12-16 \%$ when the $\mathrm{CAC}$ is $101-$ 400 (intermediate risk), $2-6 \%$ when the CAC is $1-100$ (low risk), and $1-2 \%$ when the $\mathrm{CAC}=0$ (very low risk)(7-9). Available data about CAC scores are very limited in patients with PHPT with most available studies including less than 50 patients $(1-3,10,11)$. Furthermore, the Multi-Ethnic Study of Atherosclerosis (MESA) provides a unique opportunity to examine and compare the distribution of CAC on the basis of age, sex, and race/ethnicity in a cohort free of clinical cardiovascular disease and treated diabetes (12).

The goal of this study was to evaluate the CAC score in a large number of PHPT patients compared with control subjects from the MESA cohort, and to identify independent risk factors for high-intermediate risk CAC scores (CAC score > 100). 


\section{METHODS}

We performed a cross-sectional study of consecutive, sporadic PHPT patients who underwent a parathyroidectomy (PTX) (ELSEVIER LEAVE THIS ABBREVIATION IN PLEASE IT IS VERY COMMON IN THIS FIELD) from April 2015 to September 2016. Exclusion criteria included history of coronary artery disease (angina, coronary syndrome, myocardial infarction), diabetes mellitus (any patient with antidiabetic medications or insulin), and severe chronic kidney disease (GFR $<30 \mathrm{~mL} / \mathrm{min} / 1.73 \mathrm{~m}^{2}$ ). These exclusion criteria were selected, because they should be applied when using the MESA public data and are independent risk factors for coronary calcium in the general population $(8,9,12)$. Also excluded were patients diagnosed with benign familial hypocalciuric hypercalcaemia, multiple endocrine neoplasia, and patients taking lithium or thiazide diuretics. All included patients consented to participate (CNIL nDC2014-2114). This study was approved by our institutional review board and registered at clinicaltrials.gov (NCT03410394).

All PHPT patients were included at the preoperative clinical visit and were evaluated (biologic workup, cardiac computed tomography [CT]) during the interval before PTX (about 6 weeks). The diagnosis of PHPT was made based on the presence of hypercalcemia with an inappropriately normal or increased parathyroid hormone level $(4,5,13)$. PHPT patients were classified according to the 4th International Workshop Guidelines and the guidelines of the American Association of Endocrine Surgeons (AAES) for PTX: serum calcium $>1 \mathrm{mg} / \mathrm{dL}$ above the upper normal limit, bone density $\mathrm{T}$ score $<-2.5$ at any site, creatinine clearance $<60 \mathrm{~mL} / \mathrm{min}, 24-\mathrm{h}$ urine calcium $>400 \mathrm{mg} /$ day, presence of kidney stones, and age less than $50(4,5)$. Patients were also classified according to PHPT clinical phenotypes $(14,15)$. The mild 
normocalcemic group comprised of patients with a serum calcium concentration at the upper limit of normal $(<104 \mathrm{mg} / \mathrm{L}$ or $2.60 \mathrm{mmol} / \mathrm{L})$ with an inappropriately high level of PTH (> $35 \mathrm{ng} / \mathrm{L}$ ). The mildly hypercalcemic group comprised of patients with a serum calcium concentration ranging from 104 to $114 \mathrm{mg} / \mathrm{L}$ (2.60 and $2.85 \mathrm{mmol} / \mathrm{L})$ with an inappropriately high level of PTH (15). The classic hypercalcemic group comprised of patients with a serum calcium concentration $>114 \mathrm{mg} / \mathrm{L}$ ( $>1 \mathrm{mg} / \mathrm{dL}$ above the upper normal limit) with an inappropriately high level of PTH (15). All patients underwent a PTXand final pathology confirmed one or more abnormal gland(s) in all of them (adenoma or hyperplasia).

Data from patients were collected on patient age, sex, BMI, antihypertensive medication, lipid-lowering medication, smoking status (currently smoking or quit smoking within the last year before parathyroidectomy), systolic blood pressure (SBP in $\mathrm{mmHg}$ ), diastolic blood pressure (DBP in $\mathrm{mmHg}$ ), and mean arterial pressure (MAP in $\mathrm{mmHg})(1)$. Blood tests included total serum calcium $] \backslash(85-104 \mathrm{mg} / \mathrm{L}$ or $8.5-10.4 \mathrm{mg} / \mathrm{dL})$, phosphate $(25-45 \mathrm{mg} / \mathrm{L}$ or $2.5-4.5 \mathrm{mg} / \mathrm{dL})$, serum parathormone (15-65 $\mathrm{ng} / \mathrm{L}$ or $\mathrm{pg} / \mathrm{mL}$ ), serum $25-\mathrm{OH}$-vitamin $\mathrm{D}$ ( $\geq 30 \mathrm{ng} / \mathrm{mL}$ ), glomerular filtration rate (MDRD in $\left.\mathrm{ml} / \mathrm{min} / 1.73 \mathrm{~m}^{2}\right)$, fasting serum glycemia $(0.75-1.1 \mathrm{~g} / \mathrm{L})$, fasting serum insulin (18-173 pmol/L), HOMA-IR $\underline{\text { Homeostatic model assessment of }}$ insulin resistance defined as glucose $\mathrm{x}$ insulin / 22.5), serum osteocalcin (15$46 \mathrm{ng} / \mathrm{mL})$, serum bone alkaline phosphatase (5.2-24.4 microgr/L), and serum aldosterone in supine position (normal range 30-280 ng/L). 24-h urinary calcium (normal range $<400 \mathrm{mg} / 24 \mathrm{~h}$ ), pathology type (uniglandular / multiglandular disease), and specimen weight (mg), were also collected. 
Measurement of coronary artery calcium -Coronary artery calcium score (CAC score) representing coronary artery deposition of calcium was measured via a multidetector row, noncontrast CT of the coronary arteries (Revolution CT, General Electric Healthcare, Milwaukee, WI, USA). CAC was quantified by using the Agatston method, which incorporates both density (Hounsfield units) and area (surface)(6). The presence of calcification was defined as a density $>130$ Hounsfield units $(\mathrm{HU})$ in more than 3 contiguous pixels $\left(>1 \mathrm{~mm}^{2}\right)$. The Agatston method uses the weighted sum of lesions with a density $>130 \mathrm{HU}$ and multiplying the area of calcium by a factor related to maximum plaque attenuation. The sum of the scores in the left main, left anterior descending, circumflex, and right coronary arteries was considered the CAC score. The presence of CACwas defined as a positive CAC score (> $0)$ and high-intermediate risk CAC scores as a CAC score > $100(6-9,12)$.

\section{Population-based control subjects from the multi-ethnic study of} atherosclerosis (MESA) - MESA was a prospective, observational, cohort study designed to investigate subclinical cardiovascular disease in a multiethnic cohort without clinical cardiovascular disease or treated diabetes (12). This study included 6110 community-dwelling participants from 6 study sites throughout the Unites States. In those individuals, the mean age was 62 years, $68 \%$ had a BMI $>25 \mathrm{~kg} / \mathrm{m}^{2}, 42 \%$ had a history of hypertension (use of antihypertensive medications), 32\% had dyslipidemia (taking a lipid-lowering medication), and $13 \%$ were current smokers (12). At the MESA public website (http://www.mesa-nhlbi.org), an interactive form allows one to enter an age, sex, race/ethnicity, and CAC score value. Consequently, for each PHPT patient in this study, the MESA website provided the estimated probability for 
a non-zero calcium score (positive CAC score) and the estimated percentile of the observed CAC score in comparison with control subjects. This information was used to examine whether a PHPT patient had a greater or lesser CAC score relative to control subjects with adjustments for patient age, sex, and ethnicity $(8,9,12)$.

Statistical analysis - Patient characteristics were described as numbers and proportions for categorical variables and means +/- standard deviation for continuous variables. Bivariate analysis was performed between groups using the $\mathrm{x}^{2}$-test or Fisher's exact test for categorical variables and the independent samples t-test or Wilcoxon's test for continuous variables. Logistic regression analysis was performed to identify independent factors associated with CAC score $>100$. Statistical analyses were performed using Statview $^{\circledR}$ (version 5.0.1) and SPSS ${ }^{\circledR}$ software (SAS Institute Inc., Cary, NC, USA).

\section{RESULTS}

A total of 153consecutive patients underwent PTXfor PHPTduring this study period; 23(15\%) were excluded due to exclusion criteria. Thus , 130 patients were included (109 women) with a mean age of $62.7 \pm 13$ years. Mean BMI was $27.8 \pm 6 \mathrm{~kg} / \mathrm{m}^{2}\left(63 \%\right.$ had a BMI $\left.>25 \mathrm{~kg} / \mathrm{m}^{2}\right)$, and 114 patients (87\%) had uniglandular disease (Table 1). Among the 130 included patients, $57(44 \%)$ took at least one antihypertensive medication, 23 (18\%) htook one lipid-lowering medication, and 14 (11\%) were smokers (Table 2). According to the 4th International Workshop Guidelines and guidelines of the AAES forPTX, 98 of our 130 patients (75\%) met at least one of the criteria for PTX(4, 
5). According to PHPT phenotypes, 94 patients (72\%) had mild PHPT (normoand hypercalcemic), and 36 (28\%) had classic hypercalcemic PHPT $(5,15)$. The mean preoperative CAC score was $120 \pm 344$ (range 0-2587) in 130 patients. This corresponded to a mean number of calcifications per patient of $4.4 \pm 9.6$ (range $0-65$ ) with a mean volume of $87 \pm 236 \mathrm{~mm}^{3}$ (range $0-1699$ ). Mean CAC scores in the left main, left anterior descending, left circumflex, and right coronary arteries were $18 \pm 54,43 \pm 127,18 \pm 113$, and $41 \pm 135$, respectively. Distribution of CAC scores and corresponding risk for a 10-year coronary event were detailed in Figure 1. Overall, 21\% of patients among all PHPT patients $(n=27 / 130)$ had either high or intermediate risk CAC scores (CAC score > 100). When CAC scores in PHPT patients were compared with control subjects, we observed that the percentage of positive CAC scores was similar in both groups (53 \% versus $50 \%, p=n s)$. The mean CAC score values in patients with positive CAC scores $(n=69)$, however, was greater and at the $67^{\text {th }}$ percentile of control subjects from the MESA cohort $(p<0.001)$ (Table 3 ). In PHPT patients, the CAC score was positively correlated with patient age (OR $0.34 ; 0.18-0.48 ; p<0.001)$, number of antihypertensive medications (OR $0.21 ; 0.04-0.37 ; p=0.018$ ), and the $25-\mathrm{OH}$ vitamin D level (OR 0.19; $0.02-0.35 ; p=0.029)$, and was negatively correlated with the GFR (OR -0.21 ; $-0.37--0.04 ; p=0.015)$ and the $24 h-u r i n a r y$ calcium (OR $-0.19 ;-0.36--0.01 ;$ $p=0.035)$ (Table 4). The mean CAC score was greater in patients $(n=57)$ taking at least one antihypertensive medication $(231 \pm 484$ versus $33 \pm 111$; $p=0.001$ ), but no difference was observed between patients who did or did not take lipid-lowering medication (141 \pm 336 versus $115 \pm 347 ; p=n s)$ or between smokers versus non-smokers (61 \pm 177 versus $127 \pm 359 ; p=n s)$. 
The 32 patients in our cohort who did not meet at least one of the criteria for PTX (4th International Workshop Guidelines and AAES guidelines) had a greater mean CAC score in comparison with patients who met at least one pf the criteria for PTX(206 \pm 555 versus $91 \pm 236 ; p=0.035)$. We also observed that mean CAC score was greater in patients with mild normocalcemic PHPT compared to __ $x x x x x$ (ELSEVIER PLEASE HAVE THE AUTHORS FILL IN THE UNDERLINED PART I SUSPECT IT IS IN COMPARISON TO THE CONTROL PATIENTS BUT THEY NEED TO CLARFY THIS $)(p=0.025)($ Figure 2)(5, 15). Mean values for age, GFR, number of antihypertensive medications, and 24-h urinary calcium were similar between the 3 different PHPT phenotype group (Table 5). In contrast, the mean values for serum levels of phosphorus and $25-\mathrm{OH}$ vitamin $\mathrm{D}$ were greaterin patients with mild normocalcemic PHPT.

In multivariate analysis, patient age (OR $1.1 ; 1.1-1.2 ; p<0.001)$, patients with mild normocalcemic PHPT (OR $5.1 ; 1.1-22.6 ; \mathrm{p}=0.037$ ), and the need for antihypertensive medications (OR 6.1; 1.8-20.9; $p<0.001)$ remained independent risk factors for preoperative high or intermediate risk CAC scores $($ CAC score $>100)($ Table 6$)$.

\section{DISCUSSION}

This cross-sectional study provides insight into CAC scores in patients with sporadic PHPT. This study, similar to prior studies, indicated the greatest CAC scores observed in the left anterior descending artery (2). This study also confirmed that about $20 \%$ of PHPT patients have high or intermediate risk CAC scores (CAC > 100) with a corresponding risk for 10-year coronary 
event $>12 \%(1-3,7-11)$. Characteristics of PHPT patients in this study were similar to previous reports $(4,5,13,14,16-18)$.

This study showed that positive CAC scores were significantly more severe in PHPT patients than in control subjects, corresponding to a greater $\underline{\text { burden of atherosclerosis. This observation may provide a rational as to why }}$

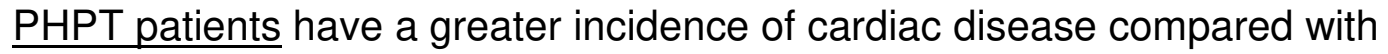
age-matched controls $(4,13,14)$. We acknowledge that this comparison could be potentially biased, $\mathrm{h}$, exclusion criteria in both groups of patients were similar as requested when using data from the MESA cohort (12). Furthermore, both groups were matched for demographics and clinical features, including $\mathrm{BMI}>25 \mathrm{~kg} / \mathrm{m}^{2}$, smoking, and patients taking antihypertensive medications (12). Patients taking lipid-lowering medications were more frequent in control subjects (32 versus 11\%), which could be considered to favor the s conclusions of our study. In addition, all PHPT patients with a GFR $<30 \mathrm{~mL} / \mathrm{min}$ (CKD stages 4 and 5 ) were excluded to avoid potential bias (19). Lastly, each comparison was performed with adjustments for patient's age, sex, and ethnicity (12).

In 2008, Streeten et al. published the only available comparative study using the MESA cohort data and found no difference in _ Xxxx____(ELSEVIER HA VE THE AUTHORS FILL THIS IN) (1); however, only 20 PHPT patients were included in their study, and most of them (95\%) were considered asymptomatic (1). Other previous studies were either noncomparative or used their own control groups without adjustments leading to potential bias $(2,3,10,11)$. This study showed that PHPT patients classified as asymptomatic and those with mild normocalcemic PHPT had significantly 
greater mean CAC score values than _ xxxx (ELSEVIER HAVE THE

AUTHORS FILL THIS IN) _. These data give evidence to the fact that patients labelled as "asymptomatic" using current guidelines actually have substantial enough symptoms or effects related to the hyperparathyroidism. These data provide new insight into the correlation between PHPT and cardiac disease and with further studies may help guide future guidelines and criteria for $\operatorname{PTX}(4,13,14)$.

This study also provided new knowledge in patients with mild normocalcemic PHPT showing a strong association with greater CAC scores in multivariate analysis. Mild normocalcemic PHPT is a recent entity that could represent the very early stages of PHPT, PHPT with concomitant vitamin D deficiency, or partial resistance of PTH target-tissues $(5,14,16)$. This PHPT variant is also associated with an increased risk of fatal and non-fatal cardiovascular disease $(16,18,20)$. Our study showed that coronary calcium could be one mechanism explaining this association, but we acknowledge that underlying mechanism(s) remain to be elucidated. Vitamin D deficiency does not explain our findings, because serum vitamin D levels were greater in this subgroup of patients. Similarly, renal function was similar between PHPT phenotype groups. Mean serum phosphorus levels were greater in patients with mild normocalcemic and could explain why those patients had greater CAC scores (1). We also acknowledge that the definition of mild normocalcemic PHPT used in this study did not include a normal ionized calcium blood level and could lead to potential biases $(5,14)$; however, this definition has been published previously with similar distribution of patients with mild normocalcemic PHPT $(15,18)$. 
This study identified risk factors for high or intermediate risk CAC scores in PHPT patients. Our study showed that serum markers for bone remodelling, glucose metabolism, BMI, blood pressure values, and gland weight were not correlated with CAC score values. Although PHPT patients with antihypertensive medications were not excluded, the study data do not support the aldosterone hypothesis as a key mediator of coronary artery disease in PHPT patients (21). In contrast to a prior study, our study showed that serum calcium and parathormone levels were not correlated with CAC score values (11). Not surprisingly, patient age remained a statistically significant criterion in the multivariate analysis, because CAC score is heavily influenced by age $(8,12)$. Finally, the need for antihypertensive medications was an independent risk factor for $\mathrm{CAC}>100$. This finding corroborates the relationship between hypertension and CAC score observed in the general population (22). We believe that this new simple criterion could be used as an to recommend PTX in patients with PHPT (17).

This study has several limitations. We compared PHPT patients from Europe with US control subjects with potential unaccounted biases. The number of patients with positive CAC scores was limited, and larger studies are needed for confirmation. Patients with low serum vitamin D levels were not excluded, but recent data showed insufficient evidence to support a consistent association between thid group of patients and the CAC score (23). Smokers and patients with a GFR between 30 and $60 \mathrm{ml} / \mathrm{min} / 1.73 \mathrm{~m}^{2}$ (stage 3 CKD) were not excluded, because those conditions were compatible with the use of the MESA cohort public data. Furthermore, PHPT patients with stage 3 CKD do not have biochemical or clinical evidence of more severe 
hyperparathyroidism compared with those without CKD (24) and were also included, because we aimed to evaluate CAC scores in all patients with PHPT including those patients with end-organ effects of PHPT(25). Lastly, lipid blood levels were not evaluated in this study.

In conclusion, our study showed that positive CAC scores were significantly more severe in PHPT patients than in control subjects. PHPT patients classified as asymptomatic and those with mild normocalcemic PHPT had significantly greater mean CAC score values. These data provide new insight into the correlation between PHPT and cardiac disease, bringing new perspectives on normocalcemic PHPT patients and may provide new criteria for PTXin patients with PHPT. The impact of PTXon CAC score progression in patients with PHPT 2illhave to be addressed in future studies.

Conflicts of interest/Disclosure: All authors certify that they have no conflict of interest associated with this manuscript.

Funding/Support: none to disclose 
TABLES and FIGURES ( 6 tables and 2 figures)

Table 1 - Patient characteristics in all patients with PHPT $(n=130)$.

\begin{tabular}{|c|c|}
\hline Parameter & Value \\
\hline Age $(y)$ & $62.7 \pm 13$ \\
\hline Sex (female / male) (\%) & $109 / 21(\overline{84} / 16 \%)$ \\
\hline BMI $\left(\mathrm{kg} / \mathrm{m}^{2}\right)$ & $27.8 \pm 6.3$ \\
\hline Calcium (mg/L) & $109.8 \pm 10.1$ \\
\hline Calcium (mg/dL) & $10.9 \pm 1.0$ \\
\hline Phosphorus (mg/L) & $25.7 \pm 4.9$ \\
\hline Phosphorus (mg/dL) & $2.6 \pm 0.5$ \\
\hline Parathormone $(\mathrm{ng} / \mathrm{L})(\mathrm{pg} / \mathrm{mL})($ normal range $15-65)$ & $147 \pm 116$ \\
\hline Vitamin D 25-OH $(\mathrm{ng} / \mathrm{mL})$ & $20.7+8.4$ \\
\hline Glomerular filtration rate (MDRD in $\mathrm{ml} / \mathrm{min} / 1.73 \mathrm{~m}^{2}$ ) & $86 \pm 18$ \\
\hline Glomerular filtration rate $(\mathrm{n})$ & \\
\hline $\begin{array}{l}\text { Stage } 1 \text { - normal or high GFR }(\text { GFR } \geq 90 \mathrm{~mL} / \mathrm{min}) \\
\text { Stage } 2-\text { mild CKD }(\text { GFR }=60-89 \mathrm{~mL} / \mathrm{min}) \\
\text { Stage } 3-\text { moderate CKD }(\text { GFR }=30-59 \mathrm{~mL} / \mathrm{min})\end{array}$ & $\begin{array}{l}64(49 \%) \\
52(40 \%) \\
14(11 \%)\end{array}$ \\
\hline Fasting serum glycemia $(\mathrm{g} / \mathrm{L})$ & $0.97+0.13$ \\
\hline Fasting serum insulin $(\mathrm{pmol} / \mathrm{L})$ & $92.6 \pm 89$ \\
\hline 24-h urinary calcium (mg/24h) & $317 \pm 166$ \\
\hline HOMA-IR & $3.2 \pm 2.9$ \\
\hline Serum osteocalcin $(\mathrm{ng} / \mathrm{mL})$ & $41.8 \pm 23.4$ \\
\hline Serum bone alkaline phosphatase (microgr/L) & $25.8 \pm 26.6$ \\
\hline Serum aldosterone $(\mathrm{ng} / \mathrm{L})$ & $137+112$ \\
\hline Systolic blood pressure $(\mathrm{mmHg})$ & $142 \pm 19$ \\
\hline Diastolic blood pressure $(\mathrm{mmHg})$ & $81 \pm 12$ \\
\hline Mean arterial blood pressure $(\mathrm{mmHg})$ & $102 \pm 12$ \\
\hline $\begin{array}{l}\text { Pathology } \\
\text { Uniglandular disease } \\
\text { Multiglandular disease }\end{array}$ & $\begin{array}{c}114(87 \%) \\
16(13 \%)\end{array}$ \\
\hline
\end{tabular}

HOMA-IR : Homeostatic model assessment of $\beta$-cell function and insulin resistance ; MDRD : modification in diet in renal disease ; GFR : glomerular filtration rate ; CKD : chronic kidney disease ; 
Table 2 - Clinical phenotypes and criteria for parathyroidectomy (4th

International Workshop Guidelines and AAES quidelines) in all patients with PHPT ( $n=130)$.

\begin{tabular}{|l|c|}
\hline \multicolumn{1}{|c|}{ Parameter } & Value \\
\hline Clinical phenotypes (5, 15) & $94(72 \%)$ \\
\hline Patients with mild PHPT & $37(28 \%)$ \\
- mild normocalcemic & $57(44 \%)$ \\
- mild hypercalcemic & $36(28 \%)$ \\
Patients with classical hypercalcemic HPT1 & \\
\hline Criteria for parathyroidectomy (4, 5) & $20(15 \%)$ \\
\hline Age < 50 years & $36(28 \%)$ \\
Calcium level greater than 1mg/dL above normal & $27(21 \%)$ \\
DEXA with T score <-2.5 SD & $37(28 \%)$ \\
Renal involvement & $33(25 \%)$ \\
- Stone & $14(11 \%)$ \\
- Hypercalciuria > 400 mg/24h & $98(75 \%)$ \\
- GFR < 60 mL/min & $57(44 \%)$ \\
Patients with at least one criterion for parathyroidectomy & 73 \\
\hline Patients taking antihypertensive medications (\%) & 41 \\
\hline No antihypertensive medication & 16 \\
One antihypertensive medication & \\
Two or more antihypertensive medications & $0.56 \pm 0.7$ \\
Mean number of antihypertensive medications & $23(18 \%)$ \\
\hline Patients with lipid-lowering medication (\%) & $14(11 \%)$ \\
\hline Smoker patients &
\end{tabular}

DEXA : dual-energy $x$-ray absorptiometry ; SD : standard deviation ; GFR : glomerular filtration rate 
Table 3 - Comparison between PHPT patients and control subjects from the MESA cohort with adjustment based on patient age, sex, and ethnicity (http://www.mesa-nhlbi.org)(12)

\begin{tabular}{|l|c|c|c|}
\hline & $\begin{array}{c}\text { PHPT } \\
\text { patients }\end{array}$ & $\begin{array}{c}\text { Control subjects } \\
\text { (MESA) }\end{array}$ & P value \\
\hline $\begin{array}{l}\text { Percentage of positive } \\
\text { CAC score (\%) }\end{array}$ & $53 \%$ & $50 \%{ }^{*}$ & $\mathrm{~ns}$ \\
\hline $\begin{array}{l}\text { CAC score values in patients } \\
\text { with positive CAC scores }\end{array}$ & percentile ** & reference & $\mathrm{p}<0.001$ \\
\hline
\end{tabular}

* : estimated percentage of positive CAC scores in control subjects from the MESA cohort (when entering patient's age, sex, ethnicity on MESA website); ${ }^{* *}$ : estimated percentile of the observed CAC score in comparison with control subjects with the same age, sex, and race/ethnicity (when entering patient's age, sex, ethnicity, and observed CAC score on MESA website) 
Table 4 - Correlation matrix for CAC score values in patients with PHPT

\begin{tabular}{|c|c|c|c|}
\hline Criteria & Coefficient & $\mathrm{Cl} 95 \%$ & $P$ value \\
\hline Age $(y)$ & 0.34 & $0.18-0.48$ & $<0.001$ \\
\hline 25-OH Vitamin D (ng/mL) & 0.19 & $0.02-0.35$ & 0.029 \\
\hline $\begin{array}{l}\text { number of antihypertensive } \\
\text { medications }(n)\end{array}$ & 0.21 & $0.04-0.37$ & 0.018 \\
\hline GFR (MDRD in $\mathrm{ml} / \mathrm{min} / 1.73 \mathrm{~m}^{2}$ ) & -0.21 & $-0.37--0.04$ & 0.015 \\
\hline 24-h urinary calcium (mg/24h) & -0.19 & $-0.36--0.01$ & 0.035 \\
\hline Serum Calcium $(\mathrm{mg} / \mathrm{L})(\mathrm{mg} / \mathrm{dL})$ & -0.15 & $-0.32-0.02$ & 0.081 \\
\hline $\begin{array}{l}\text { Serum Phosphorus } \\
\text { (mg/L)(mg/dL) }\end{array}$ & 0.04 & $-0.13-0.21$ & 0.650 \\
\hline $\begin{array}{l}\text { Erum Parathormone } \\
(\mathrm{ng} / \mathrm{L})(\mathrm{pg} / \mathrm{mL})\end{array}$ & -0.13 & $-0.28-0.04$ & 0.135 \\
\hline $\mathrm{BMI}\left(\mathrm{kg} / \mathrm{m}^{2}\right)$ & 0.05 & $-0.16-0.17$ & 0.955 \\
\hline Fasting serum glycemia (g/L) & 0.04 & $-0.17-0.18$ & 0.967 \\
\hline Fasting serum insulin $(\mathrm{pmol} / \mathrm{L})$ & -0.06 & $-0.24-0.12$ & 0.540 \\
\hline HOMA-IR & -0.06 & $-0.24-0.12$ & 0.525 \\
\hline Serum Osteocalcin (ng/mL) & -0.07 & $-0.24-0.11$ & 0.456 \\
\hline $\begin{array}{l}\text { Serum Bone alkaline } \\
\text { phosphatase (microgr/L) }\end{array}$ & -0.17 & $-0.35-0.02$ & 0.075 \\
\hline Serum Aldosterone (ng/L) & -0.05 & $-0.22-0.12$ & 0.537 \\
\hline Systolic blood pressure $(\mathrm{mmHg})$ & 0.14 & $-0.03-0.30$ & 0.117 \\
\hline Diastolic blood pressure $(\mathrm{mmHg})$ & 0.07 & $-0.11-0.24$ & 0.448 \\
\hline Mean arterial pressure $(\mathrm{mmHg})$ & 0.12 & $-0.06-0.28$ & 0.184 \\
\hline Pathology, gland weight (mg) & -0.04 & $-0.21-0.14$ & 0.665 \\
\hline
\end{tabular}


Table 5 - Patient characteristics according to PHPT clinical phenotypes

(5).

ELSEVIER SEE THE CRITERIA PHOSPHORUS IN THE TABLE THERE

ARE TWO LINES THE FIRST OF WHICH IS NOT CORRECT THE ONE

THAT SAYS THE SERUM PHOSP[HORIS IS 28=?- 4; I DO NOT KNOW

HOW TO DELTE IT SORRY

\begin{tabular}{|l|c|c|c|c|}
\hline Criteria * $^{*}$ & $\begin{array}{c}\text { Mild N } \\
\mathbf{n}=\mathbf{3 7}\end{array}$ & $\begin{array}{c}\text { Mild H } \\
\mathbf{n}=\mathbf{5 7}\end{array}$ & $\begin{array}{c}\text { Classical H } \\
\mathbf{n}=\mathbf{3 6}\end{array}$ & $\begin{array}{c}\mathbf{P} \\
\text { value }\end{array}$ \\
\hline Age (y) & $65 \pm 11$ & $61 \pm 13$ & $63 \pm 14$ & 0.269 \\
\hline $\begin{array}{l}\text { GFR (MDRD in } \\
\text { ml/min/1.73m }{ }^{2} \text { ) }\end{array}$ & $84 \pm 22$ & $86 \pm 17$ & $86 \pm 15$ & 0.514 \\
\hline $\begin{array}{l}\text { Antihypertensive } \\
\text { medications (n) }\end{array}$ & $0.67 \pm 0.71$ & $\begin{array}{c}0.59 \pm \\
0.75\end{array}$ & $0.39 \pm 0.59$ & 0.269 \\
\hline $\begin{array}{l}24-h \text { urinary calcium } \\
\text { (mg/24h) }\end{array}$ & $301 \pm 222$ & $306 \pm 146$ & $351 \pm 125$ & 0.096 \\
\hline $\begin{array}{l}\text { Serum Vitamin D 25-OH } \\
\text { (ng/mL) }\end{array}$ & $24 \pm 9$ & $21 \pm 8$ & $17 \pm 6$ & 0.003 \\
\hline Serum Calcium (mg/L) & $101 \pm 4$ & $109 \pm 3$ & $121 \pm 12$ & 0.001 \\
\hline Serum Calcium (mg/dL) & $10.1 \pm 0.4$ & $10.9 \pm 0.3$ & $12.1 \pm 0.1$ & 0.001 \\
\hline $\begin{array}{l}\text { Serum Phosphorus (mg/L) } \\
\text { THIS IS WRONG DELETE } \\
\text { IT }\end{array}$ & $28 \pm 4$ & $26 \pm 4$ & $23 \pm 5$ & 0.001 \\
\hline serumPhosphorus (mg/dL) & $2.8 \pm 0.4$ & $2.6 \pm 0.4$ & $2.3 \pm 0.5$ & 0.001 \\
\hline $\begin{array}{l}\text { Parathormone } \\
\text { (ng/L)(pg/mL) }\end{array}$ & $119 \pm 129$ & $116 \pm 56$ & $225 \pm 136$ & 0.001 \\
\hline
\end{tabular}

* : These criteria were used because they had a significant correlation with CAC score values (correlation matrix) or defined the PHPT patients population (calcium, phosphorus, parathormone); Mild $N$ : mild normocalcemic group patients ; Mild H. : mild hypercalcemic group patients ; Classic $\mathrm{H}$ :

classic hypercalcemic PHPT group patients 
Table 6 - Multivariate analysis (logistic regression) for CAC score $>100$ (dependent variable)

\begin{tabular}{|l|c|c|c|c|c|c|}
\hline Criteria & $\mathbf{n}$ & \multicolumn{2}{|c|}{$\begin{array}{c}\text { Bivariate } \\
\text { regression }\end{array}$} & P value & \multicolumn{2}{c|}{$\begin{array}{c}\text { Multivariate } \\
\text { regression }\end{array}$} \\
\hline & & $\mathrm{OR}$ & $\mathrm{Cl} \mathrm{95 \%}$ & & $\mathrm{OR}$ & $\mathrm{Cl} 95 \%$ \\
\hline Age (y) & 130 & 1.1 & $1.1-1.2$ & $<0.001$ & 1.1 & $1.1-1.2$ \\
\hline Antihypertensive & & & & & & \\
$\begin{array}{l}\text { Medications } \\
\quad \text { No }\end{array}$ & 73 & 1 & & & 1 & \\
$\quad$ Yes & 57 & 11.7 & $3.7-36.4$ & $<0.001$ & 6.1 & $1.8-20.9$ \\
\hline $\begin{array}{l}\text { Clinical phenotypes } \\
\quad \text { Classical H }\end{array}$ & 36 & 1 & & & & \\
$\quad$ Mild H & 57 & 1.7 & $0.5-5.9$ & & 1 & \\
$\quad$ Mild N & 37 & 4.3 & $1.3-15$ & 0.037 & 5.1 & $0.5-10.4$ \\
\hline
\end{tabular}

Mild $\mathrm{N}$ : mild normocalcemic group patients ; Mild $\mathrm{H}$. : mild hypercalcemic group patients ; Classic $\mathrm{H}$ : classic hypercalcemic PHPT group patients 
Figure 1 - CAC scores in 130 patients with PHPT according to the risk for 10-year coronary event (American College of Cardiology)(7-9). CAC scores were $>400$ in 13 patients (10\%)(high risk for 10-year coronary event: 22-28\%), between 101 and 400 in 14 patients (11\%)(intermediate risk for 10year coronary event: 12-16\%), between 1 and 100 in 42 patients (32\%)(low risk for 10-year coronary event: 2-6\%), and null in 61 patients (47\%)(very low risk for 10-year coronary event: $1-2 \%$ ).

Figure 2 - Mean CAC scores in 130 PHPT patients according to clinical phenotypes $(5,15)$. Mean CAC score was significantly higher in mild normocalcemic PHPT patients, followed by mild hypercalcemic PHPT patients, and lower in patients with classical hypercalcemic PHPT $(241 \pm 536$ versus $91 \pm 257$ versus $41 \pm 103 ; p=0.025)$, respectively. 


\section{REFERENCES (25 max)}

1. Streeten EA, Munir K, Hines S, Mohamed A, Mangano C, Ryan KA, et al. Coronary artery calcification in patients with primary hyperparathyroidism in comparison with control subjects from the multi-ethnic study of atherosclerosis. Endocr Pract. 2008; 14:155-61.

2. Dural C, Okoh AK, Seicean A, Yigitbas H, Thomas G, Yazici P, et al. A pilot study investigating the effect of parathyroidectomy on arterial stiffness and coronary artery calcification in patients with primary hyperparathyroidism. Surgery. 2016;159:218-24.

3. Mesquita PN, Dornelas Leão Leite AP, Chagas Crisóstomo SD, Veras Filho E, da Cunha Xavier L, Bandeira F. Evaluation of coronary calcium score in patients with normocalcemic primary hyperparathyroidism. Vasc Health Risk Manag. 2017;13:2259.

4. Wilhelm SM, Wang TS, Ruan DT, Lee JA, Asa SL, Duh QY, et al. The American Association of Endocrine Surgeons Guidelines for Definitive Management of Primary Hyperparathyroidism. JAMA Surg. 2016;151:959-68.

5. Silverberg SJ, Clarke BL, Peacock M, Bandeira F, Boutroy S, Cusano NE, et al. Current issues in the presentation of asymptomatic primary hyperparathyroidism: proceedings of the Fourth International Workshop. J Clin Endocrinol Metab 2014;99:3580-94.

6. Agatston AS, Janowitz WR, Hildner FJ, Zusmer NR, Viamonte M Jr, Detrano R. Quantification of coronary artery calcium using ultrafast computed tomography. J Am Coll Cardiol. 1990;15:827-32.

7. Arnson Y, Rozanski A, Gransar H, Friedman JD, Hayes SW, Thomson LE, et al. Comparison of the Coronary Artery Calcium Score and Number of Calcified Coronary Plaques for Predicting Patient Mortality Risk. Am J Cardiol. 2017;120:2154-9.

8. Detrano R, Guerci AD, Carr JJ, Bild DE, Burke G, Folsom AR, et al. Coronary calcium as a predictor of coronary events in four racial or ethnic groups. $\mathrm{N}$ Engl J Med. 2008;358:1336-45.

9. Greenland P, Blaha MJ, Budoff MJ, Erbel R, Watson KE. Coronary Calcium Score and Cardiovascular Risk. J Am Coll Cardiol. 2018;72:434-47.

10. Kepez A, Harmanci A, Hazirolan T, Isildak M, Kocabas U, Ates A, et al. Evaluation of subclinical coronary atherosclerosis in mild asymptomatic primary hyperparathyroidism patients. Int J Cardiovasc Imaging. 2009;25:187-93.

11. Wu G, Xu B, Wu T, Wang XY, Wang T, Zhang X, et al. Correlation between serum parathyroid hormone levels and coronary artery calcification in patients without renal failure. Biomedical reports. 2016;5:601-6.

12. McClelland RL, Chung H, Detrano R, Post W, Kronmal RA. Distribution of coronary artery calcium by race, gender, and age: results from the Multi-Ethnic Study of Atherosclerosis (MESA). Circulation. 2006;113:30-7.

13. McDow AD, Sippel RS. Should Symptoms Be Considered an Indication for Parathyroidectomy in Primary Hyperparathyroidism? Clin Med Insights Endocrinol Diabetes. 2018;Jun 27:doi: 10.1177/1179551418785135.

14. Bilezikian JP. Primary Hyperparathyroidism. J Clin Endocrinol Metab. 2018;103:3993-4004. 
15. Bannani S, Christou N, Guérin C, Hamy A, Sebag F, Mathonnet M, et al. Effect of parathyroidectomy on quality of life and non-specific symptoms in normocalcaemic primary hyperparathyroidism. Br J Surg. 2018;105:223-9.

16. Anastasilakis DA, Makras P, Polyzos SA, Anastasilakis AD, COMBO ENDO team 2017. Asymptomatic and normocalcemic hyperparathyroidism, the silent attack: a combo-endocrinology overview. Hormones. 2018;doi: 10.1007/s42000-018-0069-6. 17. Heyliger A, Tangpricha V, Weber C, J. S. Parathyroidectomy decreases systolic and diastolic blood pressure in hypertensive patients with primary hyperparathyroidism. Surgery. 2009;146:1042-7.

18. Yan H, Calcatera N, Moo-Young TA, Prinz RA, Winchester DJ. Degree of hypercalcemia correlates with parathyroidectomy but not with symptoms. Am J Surg. 2019;217:437-40.

19. Daniel WT, Weber C, Bailey JA, Raggi P, Sharma Y. Prospective analysis of coronary calcium in patients on dialysis undergoing a near-total parathyroidectomy. Surgery. 2013;154:1315-22.

20. Yu N, Donnan PT, Leese GP. A record linkage study of outcomes in patients with mild primary hyperparathyroidism: the Parathyroid Epidemiology and Audit Research Study (PEARS). Clin Endocrinol. 2011;75:169-76.

21. Brunaud 1, Germain A, Zarnegar R, Rancier M, Alrasheedi S, Caillard C, et al. Serum aldosterone is correlated positively to parathyroid hormone (PTH) levels in patients with primary hyperparathyroidism. Surgery. 2009;146:1035-41.

22. Aladin AI, Al Rifai M, Rasool SH, Dardari Z, Yeboah J, Nasir K, et al. Relation of Coronary Artery Calcium and Extra-Coronary Aortic Calcium to Incident Hypertension (from the Multi-Ethnic Study of Atherosclerosis). Am J Cardiol. 2018;121:210-6.

23. Malik R, Aneni EC, Roberson L, Ogunmoroti O, Ali SS, Shaharyar S, et al. Measuring coronary artery calcification: is serum vitamin D relevant?

Atherosclerosis. 2014;237:734-8.

24. Walker MD, Nickolas T, Kepley A, Lee JA, Zhang C, McMahon DJ, et al. Predictors of renal function in primary hyperparathyroidism. J Clin Endocrinol Metab. 2014;99:1885-92.

25. Assadipour Y, Zhou H, Kuo EJ, Haigh PI, Adams AL, Yeh MW. End-organ effects of primary hyperparathyroidism: A population-based study. Surgery.

2018;165:99-104. 
Figure 1

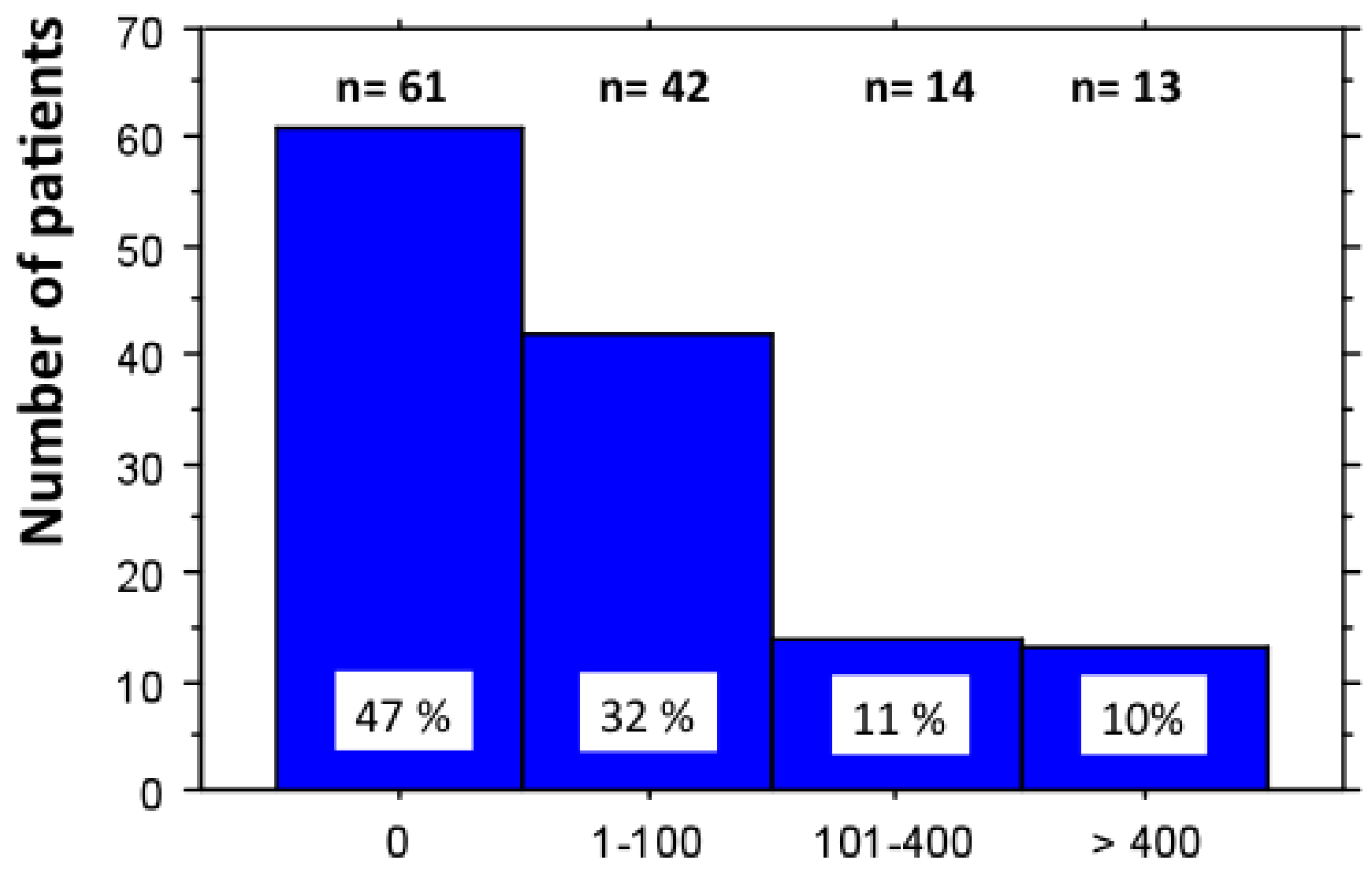

CAC scores 
Figure 2

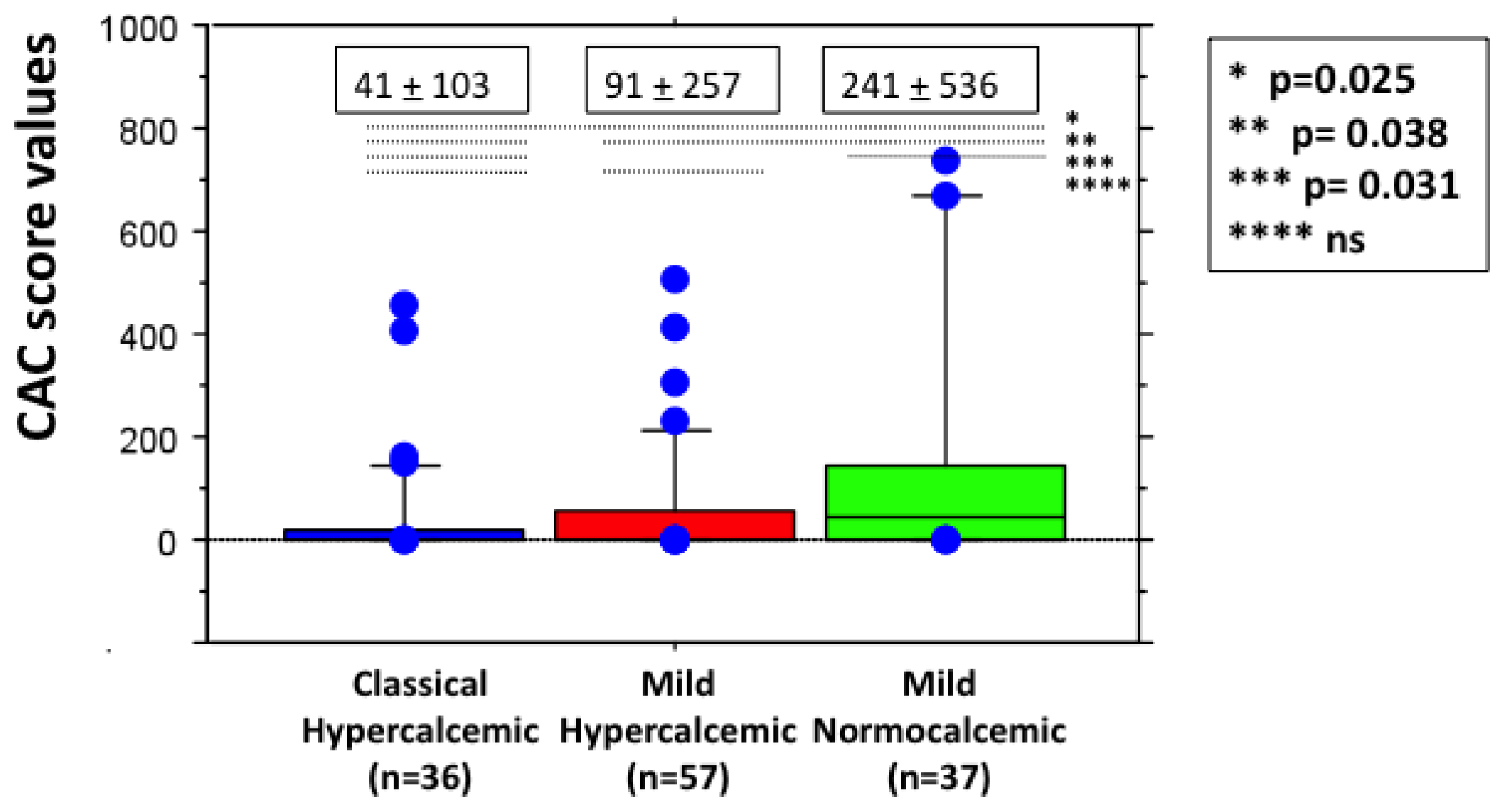

